\title{
Influence of Surface Treatment and Crosslinking Density on the Rheological and Mechanical Properties of Particle Filled Elastomers
}

\author{
Kazuyuki SHOHARA, Kousuke UOTANI, and Hideki YAMANE
}

\begin{abstract}
Division of Advanced Fibro-Science, Kyoto Institute of Technology, Matsugasaki, Sakyo-ku, Kyoto 606-8585, Japan
Influence of surface treatment and crosslinking density on the rheological and mechanical properties of silicone resin filled with silica particles was investigated. Although addition of particle in the liquid silicone matrix increased the storage modulus $G^{\prime}$ and the complex viscosity $\left|\eta^{*}\right|$ especially at a low frequency region, surface treatment of particle suppressed such tendency. On the other hand, surface treatment increased the storage modulus $E^{\prime}$ and the tensile modulus $E$ of crosslinked elastomers. Particle unfilled silicone elastomer showed an increasing storage modulus with temperature at a rubbery region behaving as an entropy elastomer and highly particle filled elastomers showed a decreasing storage modulus indicating an enthalpy elastic character. However silicone elastomers with small particle content changed their character from entropy elastic to enthalpy elastic with increasing crosslinking density.

Key Words: Silicone resin / Dynamic viscoelasticity / Tensile property / Surface treatment / Crosslinking density
\end{abstract}

\section{微粒子充填エラストマーのレオロジーおよび 力学的性質に及ぼす微粒子表面処理と架橋密度の影響}

\author{
正原 和幸，魚谷 耕輔，山根 秀樹
}

(原稿受理：2003年7月30日）

1. 緒言

マトリックスと微粒子の界面に強固な化学結合を発現さ せる手段として表面処理がある. 11-5) シランカップリング剂は 代表的なもので，1分子中に無機材料と結合可能な加水分解 基と有機マトリックスと結合可能な有機官能基を持つ. これ を用いた微粒子の表面処理により単に複合材料の力学的性 質を向上させるだけでなく, 電気・磁気特性の改良や, 耐水 性, 耐候性, 而熱性, 分散性, 密着性, 加工性の改良など数 多くの目的に使用される. ${ }^{5}$

著者らは非常に柔軟性に富む液状シリコーン樹脂に様々 なシリカ微粒子を充填させ，レオロジー的性質とシリカ微粒 子分散状態, およびこれを架橋したシリカ微粒子充填シリ コーンエラストマーのレオロジー的性質, 力学的性質とシリ 力微粒子分散状態との関係を評価した。の 微粒子充填エラス トマーの物性は微粒子の充填だけでなく, マトリックスと微 粒子の界面特性やマトリックスの架橋密度によっても影響 されると考えられる．そこで本研究ではビニル基を有するシ ランカップリング剤で表面処理を施したシリカ微粒子を充 填した液状シリコーン樹脂と, 架橋したエラストマーのレオ ロジー的, 熱的および力学的性質について検討した. さらに マトリックスの架橋密度の影響についても評価した。
2. 実 験

\section{1 試料}

マトリックスであるシリコーン樹脂（NS010；信越化学） は両末端と側鎖にビニル基を有し，白金触媒（CAT-PL-50T； 信越化学) 存在下で架橋剂（D4007；信越化学）とヒドロシ リル化反応によりシリコーンエラストマーとなる. ${ }^{6}$ シリカ 微粒子は粒径 $1.3 \sim 2.0 \mu \mathrm{m}$, 比表面積2 $5 \mathrm{~m}^{2} / \mathrm{g}$, 球形の親水性表 面を有するSOC5（アドマテックス）を用いた．微粒子の表面 処理剤としてビニルトリエトキシシラン（VTES ; 信越化学） を使用した。

\section{2 試 料 調 製}

シリコーン樹脂 $15 \mathrm{~g}$ ，キシレン $35 \mathrm{~g}$ ，トルエン $52.9 \mathrm{~g}$ ，重合 遅延剤（PLR-1；信越化学株式会社） $0.5 \mathrm{~g}$ の混合物に微粒子を 所定量混合し，日本精機製作所エースホモジナイザー AM-5 にて回転数 10000 で 20 分間擋拌した. 撹拌後, 室温で 17 時間, $50^{\circ} \mathrm{C}$ で 5 時間減圧乾燥させキシレン，トルエンを除去したも のを未架橋試料とした。この未架橋試料に架橋剤D4007 $1.5 \mathrm{~g}$ と白金触媒CAT-PL-50T 0.075g を混合しシャーレに注ぎ, $200^{\circ} \mathrm{C}$ で 30 分間加熱架橋することにより， 厚さ約 $0.1 \mathrm{~mm} の シ$ リカ微粒子充填シリコーンエラストマーフィルムを得た。

京都工芸繊維大学大学院工芸科学研究科先端ファイブロ科学専攻

京都市左京区松ヶ崎御所海道町 


\section{3 微粒子の表面処理}

SOC5 20g, イソプロパノール (IPA) 90g, 精製水 $0.06 \mathrm{~g}$ (VTES に対し $3 \mathrm{~mol}$ ），IPAで $0.1 \mathrm{wt} \%$ に希䣋した $6 \mathrm{~N}$ 塩酸 $4.1 \mathrm{~g}$ (VTESに 対し $0.03 \mathrm{~mol}$ ）を混合し，窒素雾囲気下で擋拌しながらIPAで 希釈した $10 \mathrm{wt} \% \mathrm{VTES} 2 \mathrm{~g}$ を滴下した. $50^{\circ} \mathrm{C} て ゙ 1$ 時間反応させ, ろ別後IPA $90 \mathrm{~g}$ で洗浄し, 再度ろ別したものを $50^{\circ} \mathrm{C}$ で一昼夜 乾燥することにより表面にビニル基が導入されたシリカ微 粒子を調製した.VTESにより表面処理を施したSOC5微粒子 をV-SOC5と呼ぶ。

\section{4 測 定}

未架橋試料の動的粘弾性の周波数依存性はBohlin Rheometer CSMを用いて測定した, 直径 $25 \mathrm{~mm}$ のパラレルプレートモー ド, 室温 $\left(25^{\circ} \mathrm{C}\right)$, 角周波数 $10^{-2} \sim 10^{2} \mathrm{rad} / \mathrm{s}$, 歪 $0.5 \%$, プレート 間のギャップは $1 \mathrm{~mm}$ とした. 未架橋試料の微粒子分散状態は スライドガラスに試料を挟み光学顕微鏡NIKON OPTIPHOT2POLにて観察した. 架橋試料の動的粘弾性の温度依存性は UBM Rheogel-E4000を用い温度範囲 $-150^{\circ} \mathrm{C} \sim 100^{\circ} \mathrm{C}$, 昇温速度 $3^{\circ} \mathrm{C} / \mathrm{min}$, 周波数 $128 \mathrm{~Hz}$, チャック間距離 $15 \mathrm{~mm}$ で $0.07 \%$ の伸長 歪を与えて測定した. 試料は長さ $25 \mathrm{~mm}$, 幅 $5 \mathrm{~mm}$, 厚さ $0.7 \mathrm{~mm}$ の短冊状とした. 示差走查熱量測定 (DSC) はブルカー・エ イエックスエスDSC3100SAを用い窒素雰囲気下, 昇温速度 $3^{\circ} \mathrm{C} / \mathrm{min}$ で測定した. 引張試験は米倉製作所製のCATY500BH を用い引張速度 $100 \mathrm{~mm} / \mathrm{min}$, チャック間距離 $20 \mathrm{~mm}, 25^{\circ} \mathrm{C}$ で 測定した. 試料は長さ $50 \mathrm{~mm}$, 幅 $5 \mathrm{~mm}$, 厚さ $0.1 \mathrm{~mm}$ の短冊状 とした. 架橋試料の微粒子分散状態は引張試験後の試料の破 断面と, 液体窒素中で試料を破断させた面に金蒸着を施し, 日立製作所 S-800型電解放出型走查電子顕微鏡（FE-SEM）を 用いて観察した.

\section{3. 結果と考察}

\section{1 未架橋試料のレオロジー的性質}

微粒子未充填試料およびSOC5 と V-SOC5 充填試料の貯蔵弹 性率 $G^{\prime}$ (a) と複素粘性係数の絶対值 $\left|\eta^{*}\right|$ (b) の周波数依存性を Fig. 1に示寸. 微粒子未充填試料および $5 \mathrm{wt} \%$ の微粒子を充填し た試料は低周波数側で $G^{\prime} の$ 対数と周波数の対数が比例する液 状高分子のプロファイルを示した. 7,8) 微粒子高充填試料では
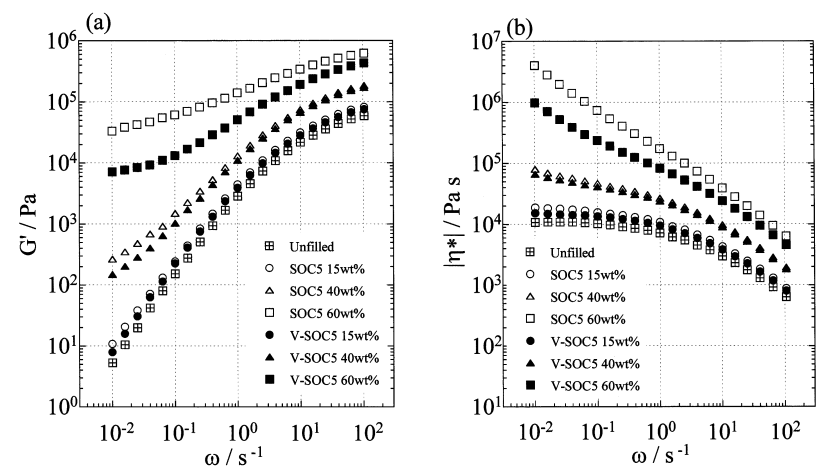

Fig.1 Storage modulus, $G^{\prime}$ (a) and complex viscosity, $\left|\eta^{*}\right|$ (b) of silicone resin filled with SOC5 and V-SOC5 as functions of angular frequency.
表面処理の有無に関わらず $G^{\prime}$ と $\left|\eta^{*}\right|$ の充填率による影響は 低周波数側で著しく高周波数側で小さくなっている.SOC5 と V-SOC5の充填率を増加させると $G^{\prime}$ が増大し, 低周波数側には 微粒子充填率が $40 \mathrm{wt} \%$ で僅かに第2平坦部が観察され, $60 \mathrm{wt} \%$ では明確な第2平坦部が確認できた。この第2平坦部は微粒子 が凝集して3次元網目構造を形成していることに起因寸ると 言われている. 11,8) $|\eta *|$ も微粒子充填率を増加するに伴い值 が増大した. 微粒子未充填試料や微粒子充填率が $5 \mathrm{wt} \%$ と低い 場合は低周波数側でニュートン領域を示すが，微粒子充填率 を増加させると高周波数側から低周波数側にかけて直線状 に值が増加する傾向を示し, 微粒子充填率が $60 \mathrm{wt} \%$ では ニュートン領域は観察されなかった.

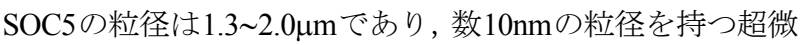
粒子と比較すると, 粒子間のファンデルワールスカや静電気 力の様な相互作用は小さく凝集を起こしにくい. しかし微粒 子充填率が $60 \mathrm{wt} \%$ に達すると低周波数側に第 2 平坦部が現れ たことから, 微粒子充填率を増加させることで 3 次元網目構 造が形成されることが分かる。凝集が成長し系全体にわたり 3次元網目構造が発達すると, 微粒子間の結合を通して力が 直接伝達されるようになり, 固体としての性質が強まる。微 粒子充填率が増加するに伴い $G^{\prime}$ と $\left|\eta^{*}\right|$ が増加した理由はこ れらによるものと思われる。

一方, 表面特性の異なるSOC5 と V-SOC5を充填した試料を 比較すると $G^{\prime},\left|\eta^{*}\right|$ とも低充填率では大きな差は見られない ものの, 充填率が増加するに伴い表面処理を施したV-SOC5を 充填した試料の $G^{\prime},\left|\eta^{*}\right|$ の増加率は小さくなる傾向を示し た. 親水性粒子SOC5 の表面に存在する水酸基をビニル基に 置換すると表面は疎水性となる。この表面処理によりマト リックスと微粒子間の界面エネルギーが低下し粒子間の構 造形成性が低下したため, 微粒子充填率が増加するに伴い SOC5 充填試料と V-SOC5充填試料の $G^{\prime},\left|\eta^{*}\right|$ の差が現れてき たものと思われる.

\section{2 架橋試料のレオロジー的性質と熱的性質}

架橋剤添加率が $10 \mathrm{wt} \%$ のSOC5 充填試料およびV-SOC5 充填 試料の貯蔵弹性率 $E^{\prime}$ と $\tan \delta$ の温度依存性を Fig. 2 に示寸. 表面 処理の有無や微粒子充填率に関わらず，全ての試料の $E^{\prime} フ^{\prime}$ ロ ファイルは約 $-120^{\circ} \mathrm{C}$ 以下では平坦であるが，約 $-120 \sim-40^{\circ} \mathrm{C}$

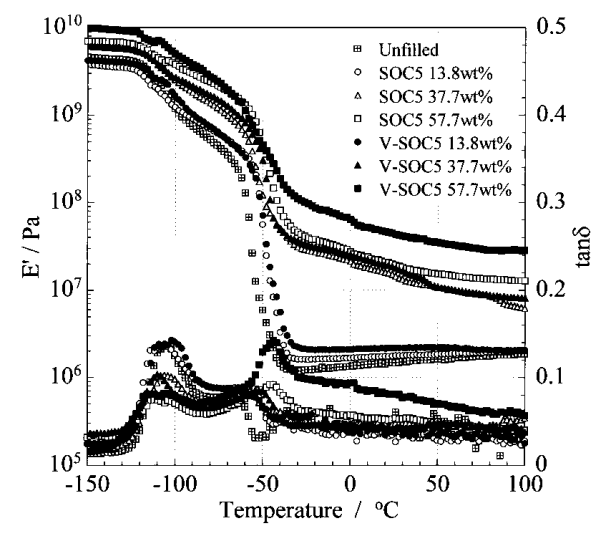

Fig.2 Temperature dependences of storage modulus, $E^{\prime}$ and tan $\delta$ of silicone elastomers filled with SOC5 and V-SOC5. Content of crosslinking agent is $10 \mathrm{wt} \%$. 
の温度範囲で急激に2段階に低下している. 約 $-40^{\circ} \mathrm{C}$ 以上にな ると再び平坦部分が現れこの領域ではゴム状を示す. $\tan \delta に$ は約 $-110^{\circ} \mathrm{C}$ と約 $-50^{\circ} \mathrm{C}$ にピークが観測された. Stevenson ら ${ }^{9}$ や著者らのによると, 低温側がシリコーンエラストマーのガ ラス転移, 高温側がシリコーンエラストマーの結晶の融解に 起因する緩和であると考えられる.

両充填試料とも微粒子の充填率が増加するに伴い, $-120^{\circ} \mathrm{C}$ 以下とゴム状領域での $E^{\prime}$ が高くなる傾向を示した。これは微 粒子充填率が増加するとマトリックスとの接触面積が増大 することで, マトリックスと微粒子界面に働くファンデル ワールスカ等の相互作用が大きくなりマトリックスが拘束 されたためと思われる. また, これらの領域における $E^{\prime}$ は微 粒子に表面処理を施したV-SOC5 充填試料の方が高くなる傾 向を示した. これは表面処理によりマトリックスと微粒子界 面の親和性が高まったこと, 微粒子表面のビニル基と架橋剤 との間のヒドロシリル化反応によりマトリックスと微粒子 間に共有結合が導入されたことによると考えられる.

微粒子未充填試料やSOC5を $13.8 \mathrm{wt} \%$ 充填した試料のゴム状 領域の $E^{\prime}$ は, 温度上昇と共にわずかに増加しており, シリコー ンエラストマーに基づくエントロピー弾性を反映している ものと思われる. 一方, 微粒子充填率が増加すると $-50^{\circ} \mathrm{C}$ 付 近では微粒子未充填試料ほど急激な $E^{\prime} の$ 低下は見られない が，ゴム状領域の $E^{\prime}$ は温度上昇と共に低下した。 これより微 粒子が形成している凝集構造のためエントロピー弾性から エネルギー弾性にその性質を変化させていることが示唆さ れる.

DSC測定の結果をFig.3(a)に, シリコーンエラストマー結晶 の融解温度 $T_{\mathrm{m}}$ と融解エンタルピー $\Delta H_{\mathrm{f}}$ を Table Iに示す. $T_{\mathrm{m}}$ は SOC5, V-SOC5 充填試料共に微粒子充填率による大きな変化

Table I Melting temperature $T_{\mathrm{m}}$ and enthalpy of fusion $\Delta H_{\mathrm{f}}$ of silicone elastomeres filled with SOC5 and V-SOC5.

\begin{tabular}{ccccc}
\hline Particle & $\begin{array}{c}\text { Particle content } \\
(\mathrm{wt} \%)\end{array}$ & $\begin{array}{c}\text { Crosslinking agent } \\
(\mathrm{wt} \%)\end{array}$ & $\begin{array}{c}\mathrm{T}_{\mathrm{m}} \\
\left({ }^{(} \mathrm{C}\right)\end{array}$ & $\begin{array}{c}\Delta \mathrm{H}_{\mathrm{f}} \\
(\mathrm{J} / \mathrm{g} \text { of silicone elastomer) }\end{array}$ \\
\hline SOC5 & 13.8 & 10 & -46.4 & 13.8 \\
SOC5 & 37.7 & 10 & -47.4 & 13.0 \\
SOC5 & 57.7 & 10 & -46.5 & 10.4 \\
\hline V-SOC5 & 13.8 & 10 & -47.3 & 11.4 \\
V-SOC5 & 37.7 & 10 & -46.6 & 10.7 \\
V-SOC5 & 57.7 & 10 & -46.9 & 8.0 \\
\hline SOC5 & 13.8 & 30 & -52.6 & 9.1 \\
SOC5 & 13.8 & 50 & -53.0 & 6.3 \\
\hline
\end{tabular}
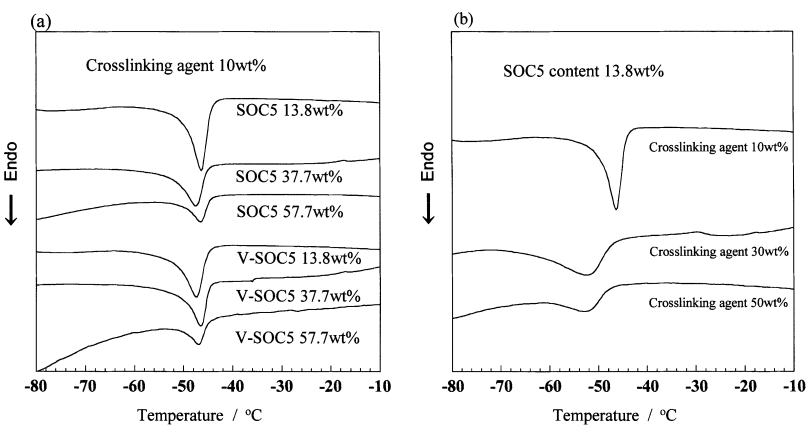

Fig.3 Effects of the contents of filler particles (a) and crosslinking agent (b) on DSC curve of particle filled elastomers.
は観察されなかった。一方, $\Delta H_{\mathrm{f}}$ は両充填試料ともに微粒子 充填率が増加するに伴い低下し, V-SOC5充填試料の方が低い 值を示している。これらの結果より微粒子充填によりシリ コーンエラストマーの結晶化が阻害され, 微粒子充填率が増 加するとその傾向が強まることが示唆される.さらにV-SOC5 充填試料は微粒子の表面処理によりシリコーン分子鎖を粒 子表面に固定しているため, 結晶化をより阻害したと考えら れる.

このように未充填試料では結晶の存在が弾性率に大きく 影響すると考えられるのに対し，微粒子充填試料では微粒子 充填率が増加すると結晶化度が低下寸るにも関わらず，約 $-120 \sim-40^{\circ} \mathrm{C}$ での $E^{\prime}$ は未充填試料よりも高い. また, 微粒子充 填試料の方が $-120^{\circ} \mathrm{C}$ 以下からの $E^{\prime}$ の低下が小さくなって いる.

架橋剤の添加率を変化させた微粒子未充填試料および SOC5 13.8wt\% 充填試料の $E^{\prime}$ と $\tan \delta$ の温度依存性を Fig.4(a), (b) に示す.これらの試料のDSC測定結果をFig.3(b) と Table Iに示
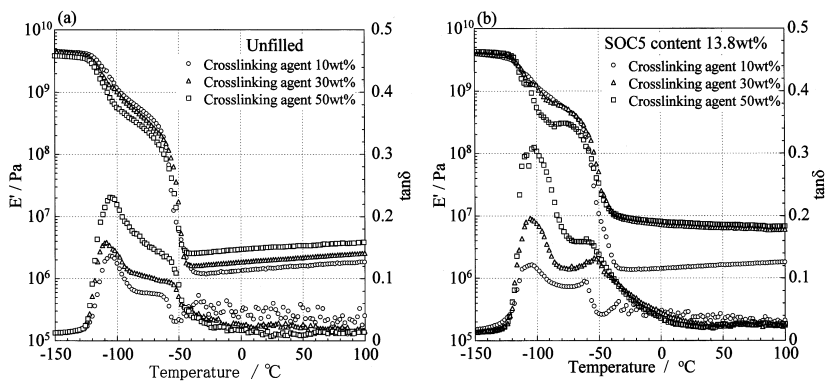

Fig.4 Temperature dependences of storage modulus and tan $\delta$ of partcicle unfilled (a) and filled (b) silicone elastomers at various crosslinking agent contents.
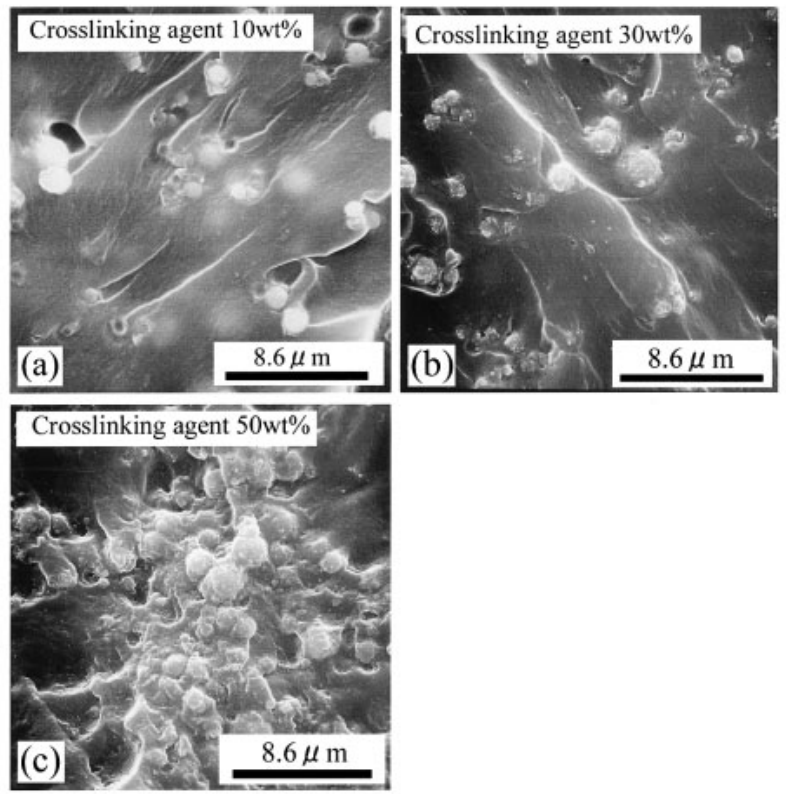

Fig.5 FE-SEM photographs of francture surface of SOC5 filled elastomers at various crosslinking agent contents. Filler content : $13.8 \mathrm{wt} \%$. 
す. 架橋剂添加率の増加と共に $\tan \delta$ のピーク強度は増大し, $T_{\mathrm{m}}, \Delta H_{\mathrm{f}}$ は低下した．架橋密度の増加により結晶化が阻害さ れたためアモルファス領域が増加したものと考えられ, その

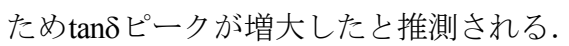

微粒子未充填試料およびSOC5 充填試料の $E^{\prime}$ は, ゴム状領域 で架橋剤の増加と共に増加した。 これら両試料の架橋剂添加 率に伴う $E^{\prime}$ の昇は, 架橋密度の増加によりマトリックスの 自由運動が抑制されたためと推定できる. 微粒子未充填試料 のゴム状領域の $E^{\prime}$ は温度上昇と共にやや増加しており, 架橋 剂添加率に関わらず全ての試料でエントロピー弾性を示し た. 一方, SOC5を $13.8 \mathrm{wt} \%$ 充填し $10 \mathrm{wt} \%$ の架橋剂を添加した 試料では，ゴム状領域の $E^{\prime}$ は微粒子未充填試料と同様に温度 上昇と共にやや増加する傾向を示すが, 架橋剤添加率が 30 , 50wt\%になると温度上昇と共に低下寸る傾向を示した. Fig.5 に示す液体窒素中で破断させた面のFE-SEM写真によると， 架橋剤添加率が増加するに伴い微粒子が凝集していく様子 が観察される。これにより Fig.4(b)で示される架橋剤添加率が $30,50 \mathrm{wt} \%$ の試料のゴム状領域の $E^{\prime}$ が温度上昇と共に低下寸 るのは, 架橋密度が高い試料では微粒子が凝集しており, こ
の構造が温度上昇により徐々に失われたためと示唆される.

\section{4 架橋試料の力学的性質}

SOC5 充填試料と V-SOC5 充填試料の引張弾性率, 引張強度, 破壊伸びをそれぞれFig.6(a)，(b)，および(c)に示す．引張弾性 率と引張強度は両試料とも微粒子充填率が $57.7 \mathrm{wt} \%$ 付近まで 上昇し，それ以上では低下する傾向が見られた。引張弾性率 は微粒子充填率が $37.7 \mathrm{wt} \%$ までは両試料間に大きな差は見ら れないが, さらに充填率が増加するとV-SOC5充填試料がより 増大した。また破壊伸びは両試料とも微粒子充填率が増加す るに伴い低下している.

引張弾性率と引張強度でSOC5 充填試料より V-SOC5 充填試 料が高くなる傾向を示したのは，微粒子の表面処理による微 粒子表面の疎水化，およびマトリックスと微粒子間に共有結 合が導入されためと考えられる.破壊伸びではV-SOC5充填試 料はSOC5 充填試料よりも低い值を示している。引張弾性率 や引張強度の結果より表面処理効果のためV-SOC5 充填試料 の方が硬くなっていることが分かり，これにより破壊伸びが 低下したと思われる。
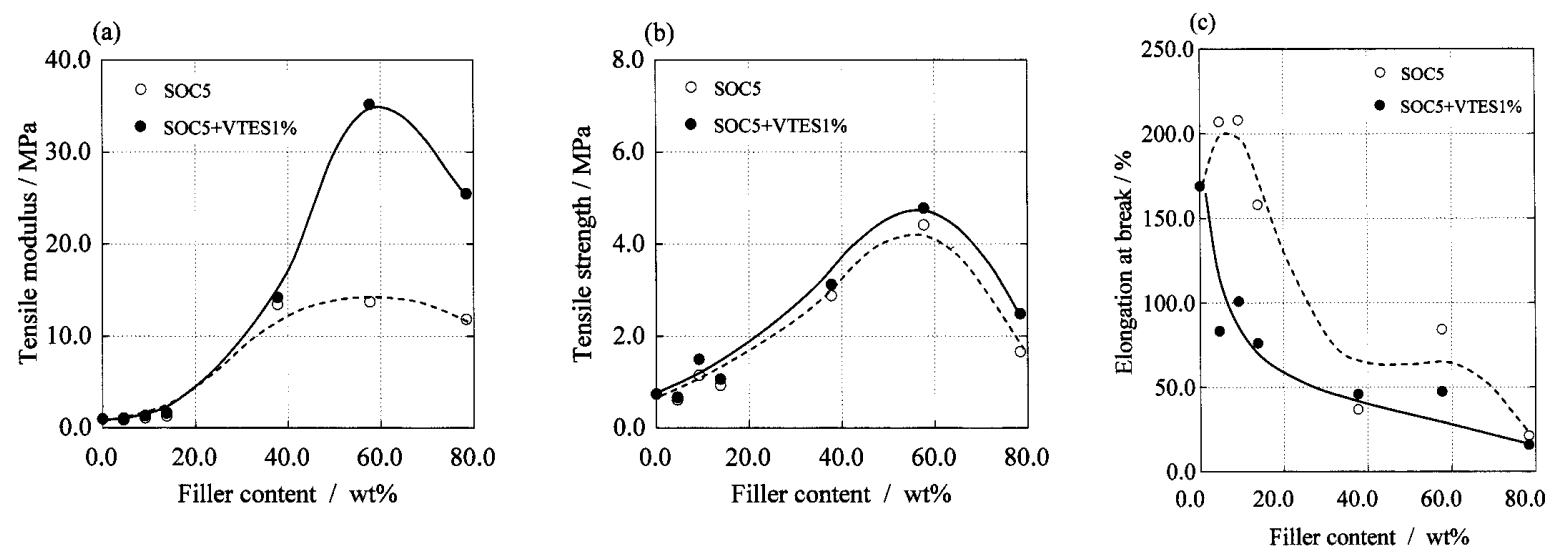

Fig.6 Mechanical properties of SOC5 and V-SOC5 filled elastomers as functions of filler content. (a) Tensil modulus, (b) Tensile strength, and (c) Elongation at break. Content of crosslinking agent : $10 \mathrm{wt} \%$.
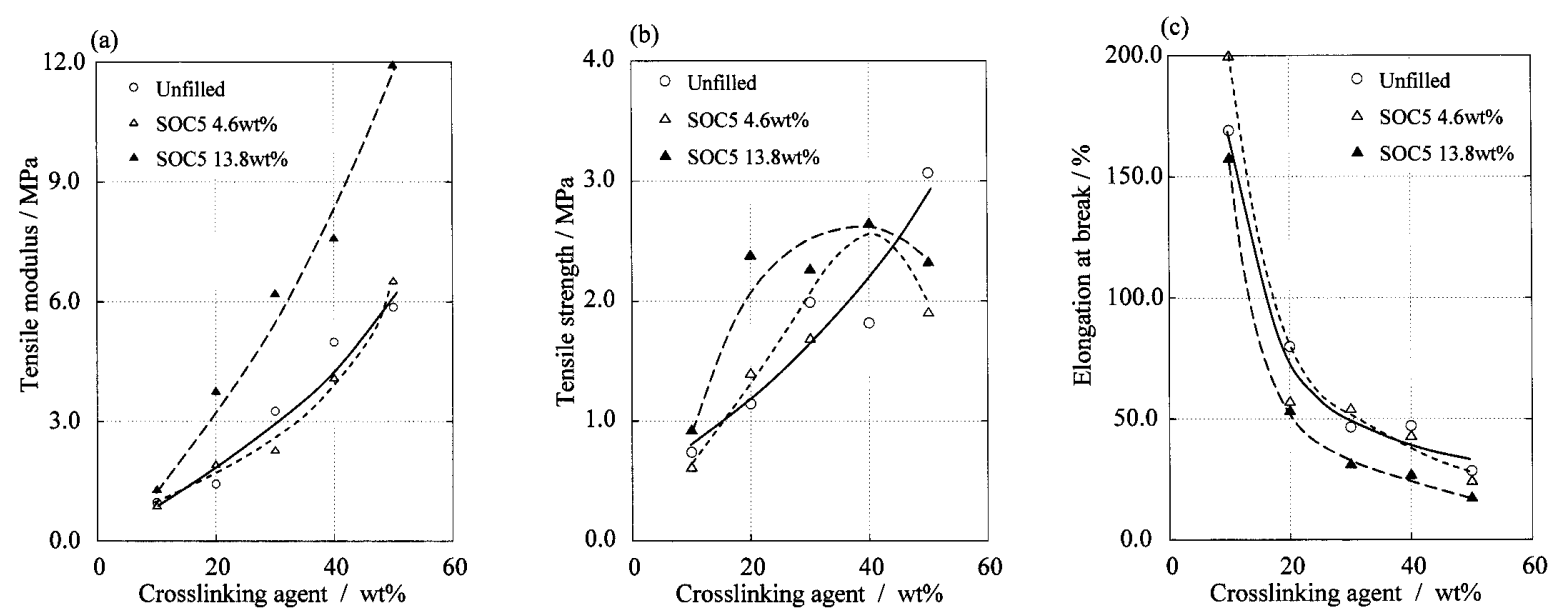

Fig.7 Mechanical properties of SOC5 filled elastomers at various crosslinking agent conttetts. (a) Tensile modulus, (b) Tensile strength, and (c) Elongation at break. 
微粒子未充填試料とSOC5 充填試料の引張弾性率, 引張強 度，破壊伸びに対する架橋剤添加率の影響をそれぞれ Fig.7(a), (b), および(c)に示す. 微粒子未充填試料の引張弾性 率と引張強度の増加は, 架橋剤添加率の増加に伴い架橋密度 が増加しマトリックスの自由運動が抑制されたためと思わ れる。.また系が硬くなるに伴い破壊伸びが低下していること が示されている.SOC5 充填試料の引張弾性率も同様に架橋剤 添加率の増加に伴い増大した. SOC5を $4.6 \mathrm{wt} \%$ 充填した試料 の引張弾性率は微粒子未充填試料と大きく変わらないが, $13.8 \mathrm{wt} \%$ では未充填試料より明確に高くなり, 架橋密度の増 加に加え微粒子充填による補強効果が現れている. 引張強度 も SOC5を $4.6 \mathrm{wt} \%$ 充填した試料では微粒子未充填試料と大き く変化はないが，架橋剤添加率が 50wt \% になると微粒子未充 填試料よりも低くなる.また微粒子充填率が $13.8 \mathrm{wt} \%$ の場合, 架橋密度の増加や微粒子充填の補強効果のため微粒子未充 填試料よりも多少高くなるが，これも架橋剤添加率が $50 \mathrm{wt} \%$ になると微粒子未充填試料よりも低くなる. 架橋剂添加率が 増加するとマトリックスが硬く脆くなる傾向が見られ, 微粒 子充填率の増加によりさらにその傾向が強まる. そのため架
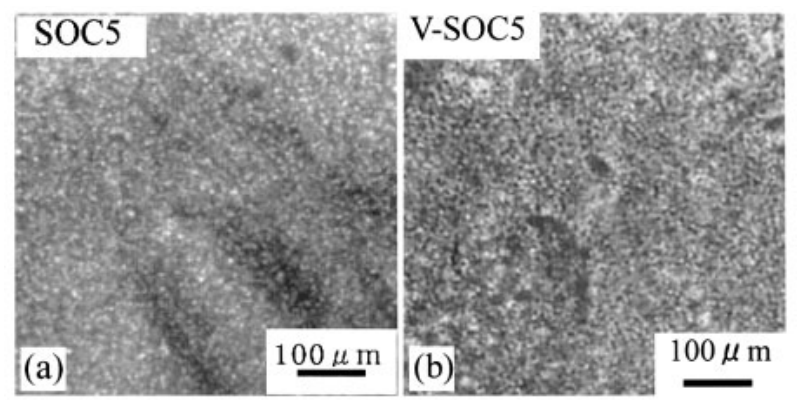

Fig.8 Optical micrographs of SOC5 and V-SOC5 filled silicone resins. Filler content : $15 \mathrm{wt} \%$.

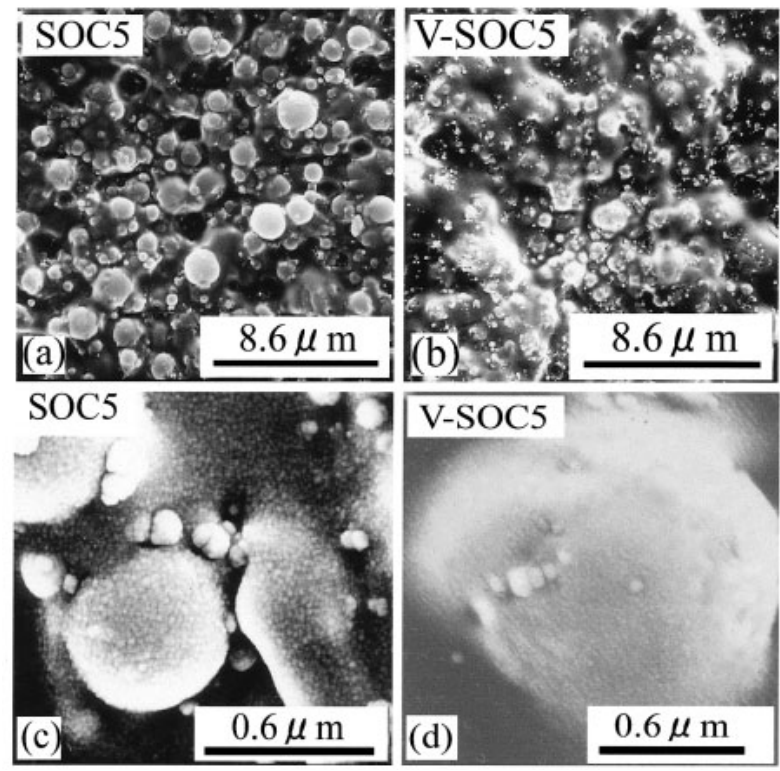

Fig.9 FE-SEM photographs of fracture surface of SOC5 and V-SOC5 filled elastomers. Filler content : $57.7 \mathrm{wt} \%$.
橋剂添加率が $50 \mathrm{wt} \%$ の試料では，微粒子充填の補強効果によ り引張弾性率は向上するが，試料が脆くなるため引張強度が 低下したと思われる。.また破壊伸びも同様に架橋剤添加率を 増加させることにより系が硬く脆くなるため低下する傾向 を示した.

\section{5 微粒子分散性}

Fig.8にSOC5 と V-SOC5を $15 \mathrm{wt} \%$ 充填した未架橋試料の光学 顕微鏡写真を示す。両試料とも単独の微粒子が観察でき表面 処理の有無による分散状態の相違は特に見られない. Fig.9に SOC5, V-SOC5 57.7wt\% 充填試料を液体窒素中で破断させた 面のFE-SEM写真を示す. 架橋試料でも表面処理の有無によ る微粒子分散性の相違は観察されなかった。しかしSOC5 充 填試料には微粒子が埋まっていた穴が多く観察され微粒子 の輪郭が明確に観察できるのに対し，表面処理を施した微粒 子ではマトリックスと密着しており, マトリックスと微粒子 の界面で破断していないことが分かる.これによりV-SOC5充 填試料ではマトリックスと微粒子界面の親和性が良いため, あるいは共有結合の存在により架橋試料のゴム状領域の $E^{\prime}$, 引張弾性率，引張強度が高くなることが説明できる. 1),10)

Fig.5に示した引張試験における破断面のFE-SEM写真によ ると, 架橋剤を $10 \mathrm{wt} \%$ 添加した SOC5 充填試料(a)では破断面 に微粒子の表面が観察されマトリックスと微粒子の界面で 破壊しており，架橋剤添加率を増加させると（(b),(c)），破壊 箇所がマトリックス内へと移行していることが分かる. 架橋 剂添加率を増加させた試料の引張試験では引張弾性率や引 張強度が低いと破断伸びは高くなることがFig.7より示され ている. 高い破断伸びを示している試料の破断直前のマト リックスと微粒子界面はボイドの存在により引き剥がされ た状態にあり，これにより破断面には微粒子表面が観察され たと推測できる. 一方, 引張弾性率や引張強度が増大すると 破断は低伸度で起こる。この時の破断はマトリックスと微粒 子界面が欠陥となる前に起こるため破断面には微粒子表面 が観察できなかったと推定される.

\section{4. 結 論}

充填微粒子の表面特性およびマトリックスの架橋密度を 変化させた微粒子充填エラストマーのレオロジー的性質, 力 学的性質および微粒子分散性を評価した. 表面処理を施した 微粒子を充填させた未架橋試料の動的粘弾性測定では, 粒子 間の構造形成が失われるため未処理の微粒子充填試料より も $G^{\prime} や\left|\eta^{*}\right|$ が低下した. 微粒子に表面処理を施した系とマト リックスの架橋密度を増加させた系の架橋試料は共にゴム 状領域の $E^{\prime}$, 引張弾性率や引張強度が増大した。 前者はマ卜 リックスと微粒子界面の親和性が向上したことや共有結合 が得られたこと, 後者は架橋密度の増加によりマトリックス の自由運動が抑制されたためであると思われる．微粒子未充 填試料では架橋密度の増加に関わらずゴム状領域の $E^{\prime}$ は温度 上昇と共にやや増加しエントロピー弾性を示したが，微粒子 充填率が増加すると試料のゴム状領域の $E^{\prime}$ は温度と共に低下 した。一方，微粒子充填率の低い試料では架橋密度が低い場 合にはエントロピー弾性挙動を示したが，架橋密度の上昇に 伴い微粒子の凝集が顕著になりエネルギー弾性的な挙動へ と変化した。 


\section{REFERENCES}

1) Nishi T, Izawa S, Akiyama S, "Polymer ABC Handobook", NTS, 480 (2001).

2) Nishimura T, “Kinousei Filler no Kaihatsugijutsu”, CMC, 292 (2000).

3) Nakamura Y, Iida T, Nihon Settyakugakkaishi, 37, 57 (2001).

4) Nakamura Y, Hida Y, Nishimura M, Iida T, Nihon Settyakugakkaishi, 37, 92 (2001).

5) Mizuno H, Tobayama M, "Hyomenshorigijutsu Handbook", NTS, 710 (2000).
6) Shohara K, Uotani K, Yamane H, Nihon Reoroji Gakkaishi, 31, 5 (2003).

7) Matsumoto T, “Bunsankei no Reoroji”, Kobunnshi Kankoukai, 75 (1997).

8) "Kouza Reoroji", Nihon Reoroji Gakkai ed, Kobunnshi Kankoukai, 31 (1992).

9) Stevenson L, David L, Gauthier C, Arambourg L, Davenas J, Vigier G, Polymer, 42, 9287 (2001).

10) Nagata K, Filler, 5, 49 (2001). 